\title{
GALLIBACTERIUM ANATIS INFECTION IN CHICKENS AND DUCKS
}

\author{
HEND K. SOROUR; NAYERA M. AL ATFEEHY and AZHAR G. SHALABY
}

Reference Laboratory for Veterinary Quality Control on Poultry Production Ministry of Agriculture, P.O. Box 264,Dokki, 12618 Giza, Egypt.

\section{ABSTRACT}

Received at: 11/8/2015

Accepted: 17/9/2015
In our investigation phenotypic and genotypic characterization were carried out for detection of Gallibacterium anatis in chickens and ducks that suffered from septicemia, perheptitis, percarditis, trachitis and penumonia. Prevalence of Gallibacterium anatis was $24 \%$ and $26 \%$ from diseased chickens and ducks respectively, The biochemical investigations differentiated the isolated strains into two starins Gallibacterium anatis biovar heamolytica with a percentage $24 \%$ and Gallibacterium anatis biovar anatis $76 \%$. Gallibacterium anatis biovar heamolytica represented $30.7 \%$ in ducks and $16.6 \%$ in chickens while Gallibacterium anatis biovar anatis was represented $69.2 \%$ in ducks and $83.3 \%$ in chickens. Antimicrobial susceptibility test insured the multidrug resistant of Gallibacterium anatis isolates. PCR technique confirms isolation percentage. Also virulence genes were examined like cytotoxic genes ( $g$ tx A1 and A2 and its results were relevant to the phenotypic virulent characteristics in addition to fimberial gene (flfA.). In conclusion some virulent genes like gtxis responsible for evoking the phenotypic character of strain such as hemolysis.

Key words: Gallibacterium anatis, Multidrug resistant, gtx gene, flf gene, poultry.

\section{INTRODUCTION}

Gallibacterium is a genus in the Gram negative bacteria that is commonly associated with poultry (Mushin et al., 1980 and Bisgaard et al., 2009). Also it was recently established within the family of Pasteurellaceae (Christensen et al., 2003). The genus contains avian bacteria formerly known as Pasteurella haemolytica like, Actinobacillus salpingitidis or Pasteurella anatis and currently includes the species Gallibacterium anatis and Gallibacterium genomospecies 1 and 2. Two biovars are described within G.anatis, a haemolytic biovar haemolytica and a non haemolytic biovar anatis. Gallibacterium spp. Can be isolated from a great variety of birds such as chickens, turkeys, ducks, geese, psittacine bird's, partridges and guinea fowl (Addoand Mohan, 1984 and Bisgaard, 1993). Some authers like Bojesen et al. (2003) mentioned that G. anatis is a common part of the normal flora of both the upper respiratory tract and lower genital tract of chickens and other avian species. G. anatisis divided into two biovars: the b-haemolytic biovar haemolytica and the non-haemolytic biovar anatis. The ability to lyse red blood cells is a prominent phenotype of pathogenic $G$. anatis isolates and the production of haemolysin is a likely virulence factor. (Christensen et al., 2003) Gallibacterium anatis has recently been recognized as a major cause of lesions in the reproductive tracts of egg layers (Neubauer $e t$ al., 2009), causing a drop in egg production and increased mortality (Bojesen et al., 2008). Multipledrug resistance (Bojesen et al., 2011) and a substantial antigenic diversity (Vazquez et al., 2006) make it difficult to prevent the negative effects of Gallibacterium anatis using traditional anti microbial agents and vaccine. In field study performed in Denmark by Bojesen et al. (2003), demonstrated that the biosecurity level influenced the prevalence of Gallibacterium spp., with alower level of biosecurity resulting in a more frequent detection of these pathogens. Fimbriae have been intensively studied, not only because they are important virulence factors of bacteria, but also because they are among the most widely used targets for the development of interventions such as vaccines (Scavone et al., 2011; Hur and Lee 2012; Wang et al., 2013). Moreover RTX-toxins are important virulence factors and responsible for haemolytic and leukotoxic activity in bacteria related to Gallibacterium (Frey and Kuhnert, 2002).

The aim of the work is isolation of the Gallibacterium spp. Associated with the diseased cases also focusing in detection of some virulent genes that may increase the signs and deaths. Finally 
studying the antibiotic susceptibility pattern to help Effective control measures are required to mitigate the economic impact on the poultry industry.

\section{MATERIALS and METHOD}

Collections of 100 samples of chickens and ducks suffering from respiratory signs (50 from each species) shown septicemia, perihepatits, pericarditis, trachitis and penumonia. The examined Samples included: trachea, liver, heart and lung.

A-Bacterial investigations of Gallibacterium anatis: 1 - Trypticase soy agar enhanced by addition of $0.05 \%$ yeast extract and 5\% newborn calf serum. (Sandhu and Richard, 1997).

\section{2- Brain heart Infusion medium (Li et al., 2011).}

3- Blood agar: within 24 hour, which is characterized as follows: circular, raised colonies with entire margin, shiny and semi-transparent with a $\beta$ heamolytic zone. Such colonies were regarded as suspicious of Gallibacterium. Suspected colonies were subcultured on blood agar to obtain pure cultures. (Neubauer et al., 2009).

\section{4- Brain heart Infusion broth:}

A- Propagation and maintenance of bacterial cultures for improved growth (Zepeda et al., 2009).

B- Preservation (Bojesen et al., 2003).

Seven hundred microlitres of Brain heart Infusion broth were mixed with $300 \mu$ l sterile glycerol $50 \%$ and stored at $-80 \circ \mathrm{C}$ until further use.

\section{5-India ink}

6- API 20 for differentiation of Gallibacterium anatis According to (Florence et al., 2008).

Table 1: API 20 for detection of Gallibacterium anatis biovar heamolytica and biovar anatis (Olsen et al., 2005).

\begin{tabular}{cccccccccc}
\hline Indole & oxidase & catalase & Motility & Sucrose & urease & ODC* & Trehalose & Sorbitol & host \\
\hline- & + & + & - & + & - & - & D & D & chicken \\
\hline- & + & + & - & + & - & + & D & + & Duck \\
\hline
\end{tabular}

ODC*: Ornithine decarboxylase,

$(+): 90 \%$ 0r more of the strains are positive

D: $11-89 \%$ of the strains are positive according to the criteria in Bergeys Manual of systematic Bacteriology

(-): $10 \%$ or less of the strains are positive.

7- Antimicrobial suscessptalibity test for Gallibacterium anatis According to (Matthew et al., 2009).

8- Congo red binding test for detection of virulence Gallibacterium anatis according to (Berkhoff and Vinal, 1986).

\section{B- Conventional PCR technique.}

Extraction:

Gallibacterium anatis DNA was extracted using commercially available kit, QIAamp DNA Mini Kit, Catalogue no.51304.

\section{PCR Reaction:}

The different primers used in this study are described in Table (2).

\section{PCR amplification.}

It was done in a $25 \mu \mathrm{l}$ reaction containing $12.5 \mu \mathrm{l}$ of Emerald Amp GT PCR master mix (2x premix), $1 \mu 1$ of each primer ( 20 pmol conc.), $4.5 \mu \mathrm{l}$ of PCR grade water, and $6 \mu \mathrm{l}$ of template. The $\mathrm{cPCR}$ reactions were performed in a Biometra T3 thermal cycler. And the thermal profiles for the different genes were applied as discussed in the reference showed in Table (2).

The PCR products were separated by electrophoresis on $2 \%$ agarose gel and photographed by a gel documentation system (Alpha Innotech, Biometra).

Table 2: Oligonucleotide primers and sequences encoding for detection of Common gene, flfA gene and $g t x A$.

\begin{tabular}{|c|c|c|c|c|}
\hline Target gene & Primer & Primer sequence $\left(5^{\prime}-3^{\prime}\right)$ & $\begin{array}{c}\text { Size of } \\
\text { Amplicon (bp) }\end{array}$ & Reference \\
\hline \multirow{2}{*}{$\begin{array}{l}\text { 16SRNA \& } \\
\text { 23S RNA }\end{array}$} & $1133 \mathrm{~F}$ & TATTCTTTGTTACCACGG & \multirow[b]{2}{*}{1032} & \multirow[t]{2}{*}{ Bojesen et al. (2007) } \\
\hline & $114 \mathrm{R}$ & GGTTTCCCCATTCGG & & \\
\hline \multirow[t]{2}{*}{ flfA } & $1162 \mathrm{~F}$ & CACCATGGGTGCATTTGCGGATGATCC & \multirow[b]{2}{*}{538} & \multirow[t]{2}{*}{ Bager et al. (2013) } \\
\hline & $1162 \mathrm{R}$ & TATTCGTATGCGATAGTATAGTTC & & \\
\hline \multirow{2}{*}{$\begin{array}{l}\text { GTX -N } \\
\text { terminal }\end{array}$} & GalNtxF & TGCGCAAGTGCTAAATGAAG- & \multirow[b]{2}{*}{925} & \multirow[t]{2}{*}{ Paudel et al. (2013). } \\
\hline & GalNtxR & GGATAATCGTTGCGCTTTG- & & \\
\hline
\end{tabular}




\section{RESULTS}

According to morphological characters and biochemical reactions the Gallibacterium was $24 \%$ $(12 / 50)$ in diseased examined chickens and 26\% $(13 / 50)$ in diseased examined ducks.

Differentiation between the hemolytic and nonhemolytic Gallibacterium was defined using the blood agar which was characterized as follows: circular, raised colonies with entire margin, shiny and semi-transparent with a $\beta$ heamolytic zone. The phenotypical studies insured that all isolates of Gallibacterium were virulent $100 \%$ when detected by congo red test, API $20^{\mathrm{TM}}$ used for differentiation of Gallibacterium anatis into Gallibacterium anatis biovar heamolytica and Gallibacterium anatis biovar anatis as detailed characters in Table (1) also results of classification are described in Table (3).

Table 3: Results of classification of gallibacterium anatis into two biovars, $\beta$ haemolytic biovar haemolytica and non- haemolytic anatis on blood ager and API 20.

\begin{tabular}{lcccc}
\hline Type of bird & \multicolumn{2}{c}{$\beta$ haemolytic gallibacterium } & \multicolumn{2}{c}{ non- haemolyticanatis } \\
\cline { 2 - 5 } & Number & $\%$ & Number & $\%$ \\
\hline Chickens & $2 / 12$ & $16.6 \%$ & $10 / 12$ & 83.3 \\
\hline Ducks & $4 / 13$ & $30.7 \%$ & $9 / 13$ & 69.2 \\
\hline Total & $6 / 25$ & $24 \%$ & $19 / 25$ & $76 \%$ \\
\hline
\end{tabular}

Antimicrobial susceptibility test resulted that Gallibacterium anatis were characterized by multidrug resistant. Gallibacterium anatis isoltates were resistant $100 \%$ to Ampicillin, Gentamycin 10, Erytheromycin 15, Ciprofloxacin 5, Chloramphenicol 30, lincospectinomycin, Doxycycline, Tetracycline Streptomycin, Naldixic acid, Enerfloxacin, Neomycin and Lincomycin, while the resistant percentage was $78.5 \%$ to Sulphamethazole and Trimethoprim, $57.1 \%$ to clostin sulphate and 50\% to Pencillin.
The isolation results were confirmed by PCR technique using 16S RNA and 23S RNA common primer for the Gallibacterium anatis Also the results for the two examined virulent gene for GtxA (cytolytic- hemolytic gene) and flf A fimberial gene are described in Table (4). Figure 1 and 2, Showed the positive amplification for the two examined virulence genes.

Table 4: PCR results for the different examined genes.

\begin{tabular}{llc}
\hline \multicolumn{1}{c}{ Type of bird } & chickens & Ducks \\
\hline $\begin{array}{l}\text { PCR identification of isolated isolates by 16S RNA\&23S RNA } \\
\text { (common species specific) }\end{array}$ & $12 / 12(100 \%)$ & $13 / 13(100 \%)$ \\
\hline $\begin{array}{l}\text { Detection of virulence gene by using PCR } \\
\text { 1- Toxin gene GTX A1 }\end{array}$ & $7 / 12(58 \%)$ & $5 / 13(38.4 \%)$ \\
\hline 2- Flagellar gene & $6 / 12(50 \%)$ & $2 / 13(15.38 \%)$ \\
\hline
\end{tabular}




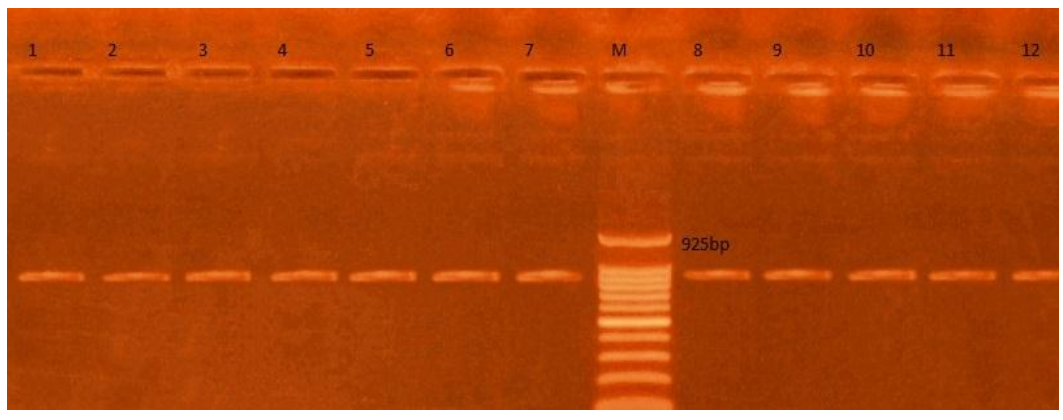

Fig. 1: positive amplification of G. anatis isolates for $g t x A 1$ gene from left to right, lane (M) ladder (QIAGEN, $G m b h)(100+b p)$, the positive amplification of $g t x A 1$ gene at $925 \mathrm{bp}$

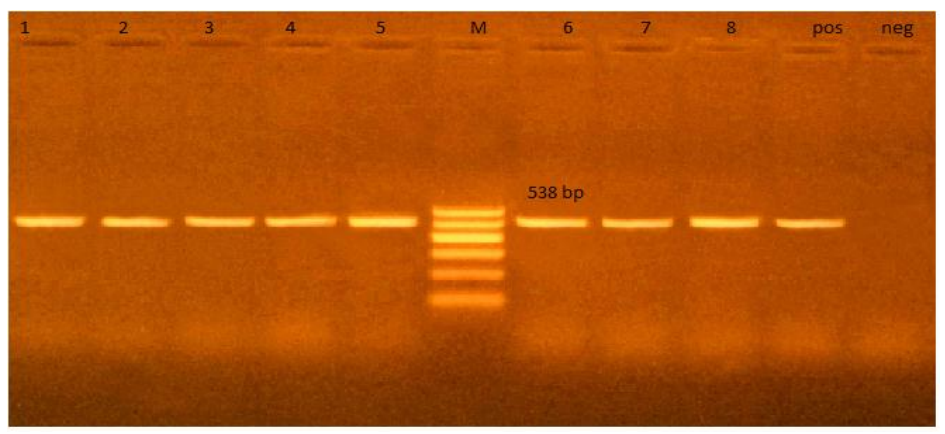

Fig. 2: positive amplification of G. anatis isolates for flfA gene, from left to right, lane (M) $100 \mathrm{bp}$ ladder (QIAGEN, Gmbh) (100-600 bp), (negative control), (positive control), the positive amplification of flfA gene at 538bp.

\section{DISCUSSION}

The global demand for meat and animal products is raising as the world population and income increases. Poultry meat and eggs are considered very important and highly sustainable components of the future global diet (AVEC, 2011), Pasteurellaceae are bacteria with an important role as primary or opportunistic, mainly respiratory, pathogens in domestic and wild animals. Some species of Pasteurellaceae cause severe diseases with high economic losses in commercial animal husbandry and are of great diagnostic concern. (Florence et al., 2008).

In our investigation Gallibacterium anatis was diagnosed in chickens and ducks that were suffered from septicemia, periheptitis, pericarditis, trachitis and penumonia The prevelance of Gallibacterium anatis was $24 \%$ in examined chickens and $26 \%$ inexamined ducks This agrees with Neubauer $e t$ al. (2009) who reported isolation of Gallibacterium in pure cultures of samples from birds with various pathological lesions. Evidently, the organism is capable of causing serious, systemic infections affecting multiple organ systems but the mechanisms of pathogenesis remain obscure. We differentiated the isolates into Gallibacterium anatis biovar heamolytica $24 \%$ and Gallibacterium anatis biovaranatis $76 \%$. Gallibacterium anatis biovar heamolytica was represented $30.7 \%$ in ducks and $16.6 \%$ in chickens while Gallibacterium anatis biovar anatis was represented $69.2 \%$ in ducks and $83.3 \%$ in chickens these results were previously explained by (Addoand Mohan,1984 Bisgaard, 1993) that the genus contains avian bacteria formerly known as Pasteurella haemolytica like, Actinobacillus salpingitidis or Pasteurella anatis and currently includes the species Gallibacterium anatis and Gallibacterium genomospecies 1and 2. Two biovars are described within G.anatis, a haemolytic biovar haemolytica and a non haemolytic biovar anatis. The haemolytic activity of Gallibacterium spp. was very prevalent in the Danish chicken production system of low to moderate biosecurity level, as recorded by Anders et al. (2003). Indicating that lesser biosecurity is a major risk factor for obtaining a Gallibacterium infection But this results was in contrary to that obtained in our study in which the prevalence in ducks was more than that of chickens. In our investigation, isolated Gallibacterium anatis were resistant to Gallibacterium anatis isoltates were resistant $100 \%$ to Ampicillin, Gentamycin 10, Erytheromycin 15, Ciprofloxacin 5, Chloramphenicol 30, lincospectinomycin, Doxycycline, Tetracycline Streptomycin, Naldixic acid, Enerfloxacin, Neomycin and Lincomycin, while the resistant percentage was $78.5 \%$ to Sulphamethazole and Trimethoprim, $57.1 \%$ 
to clostin sulphate and $50 \%$ to Pencillin. These finding was near to that obtained by Bojesen et al. (2011) that tested 58 strains against 23 compounds of different classes multidrug resistance was observed for $65 \%$ of the field strains and only two strains were susceptible to all compounds. Most prominently, resistance to tetracycline and sulfa-methoxazole was observed in $92 \%$ and $97 \%$ of the field strains, respectively. For comparison these figures were $67 \%$ and $42 \%$ respectively for the reference strains. Our results were close to that obtained by Jones et al. (2013) that demonstrated Gallibacterium anatis almost complete resistance to novobiocin, tylosin, lincosamide and tetracycline antimicrobials with moderate to high sensitivity to sulfonamides, fluoroquinolones and florfenicol. There was intermediate sensitivity for spectinomycin and erythromycin and variable resistance to lactam and aminoglycoside antimicrobials.

To represent possible antigenic variation between Gallibacterium fimbrial clusters, all Gallibacterium CU fimbriae were classified into five types based on fimbrial subunit phylogeny. All fimbrial clusters in which a previously described flfA homolog was detected and named as $f l f$, and those in which major fimbrial subunits were assigned to the different phylogenetic groups than flfA were named as flf 1 , $f l f 2$, flf 3 and flf4. Moreover Many researches mentioned the fimbrial structure of Gallibacterium that fimbrial subunit protein (flfA) was identified as a promising candidate that may be used to vaccinate laying hens (Bager et al., 2013; Bager et al., 2014). In our study the flfA gene represent $50 \%$ in the isolates of chicken and $15.38 \%$ from duck samples. Kudirkiene et al., 2014 cleared that from the five defined CU fimbrial clusters, the most common fimbrialcluster was $f l f 1$ found in $74 \%$ Gallibacterium genomes, followed by flf 2 and flf 3 detected in $65 \%$ and $52 \%$ of the genomes, respectively. Few virulence factors of $\mathrm{G}$. anatis have been described. One key virulence factor of $\mathrm{G}$. anatis is its RTX-like toxin named gtxA and its associated secretion system (Kristensen et al., 2010 and 2011). In our research the gtx $\mathrm{A}$ gene was detected in $7 / 12(58 \%)$ and $5 / 13(38.4 \%)$ from chickens and ducks samples respectively, Also the isolates that phenotypically lack the ability to hemolyze the RBCs are lacking the RTX toxin producing gene. These results are correlated to the results of hemolytic activity of the isolates which have the B hemolytic has the gtx gene as insured in some researches that the RTX-toxins are important virulence factors and strains lacking these genes havereduced virulence (Tascon et al., 1994; Jansen et al., 1995; Tatum et al., 1998). The virulence mechanisms possessed by G. anatis, and its role as a pathogen, have not been fully elucidated. The prototypic virulent $G$. anatis strain 12656-12 was recently sequenced. Analysis of this sequence identified a RTX-like toxin, gtxA, which contributes to G. anatis' virulence for chickens, and has cytotoxic activity (Kristensen et al., 2010). Furthermore, gtxA was identified and was found to be disrupted in nonhemolytic strains of G. anatis (Kristensen et al., 2011). Other virulence associated traits among G. anatis strains have been identified, such as protease production and hemagglutination, but the underlying genetic traits responsible for these phenotypes have not yet been determined. It has also been proposed that $\mathrm{G}$. anatis isolates vary in their virulence potential (Zepeda et al., 2010 and 2009), and amplified fragment length polymorphism (AFLP) has revealed that there is substantial genetic diversity among the Gallibacterium isolates dominating among and between successive flocks (Bojesen and Shivaprasad., 2007).

\section{REFERENCES}

Addo, P.B. and Mohan, K. (1984): Atypical Pasteuralla haemolytica type A from poultry. Avian diseases, 29, 214-217.

Anders, M.B.; Nielsen, S.S. and Bisgaard, M. (2003): Prevalence and transmission of haemolytic Gallibacterium species in chicken production system with different biosecurity levels. Avian Pathology, 32(5): 503-510.

AVEC. (2011): Annual report 2011. Assoc. Poultry Processors Poultry Trade EU Countries 41: $1-52$.

Bager, R.J.; Nesta, B.; Pors, S.E.; Soriani, M.; Serino, L.; Boyce, J.D.; Adler, B. and Bojesen, A.M. (2013): The fimbrial protein FlfA from Gallibacterium anatis is a virulence factor and vaccine candidate. Infect Immun, 81: 19641973.

Bager, R.J.; Kudirkiene, E.; da Piedade, I.; Seemann, T.; Nielsen, T.K.; Pors, S.E.; Mattsson, A.H.; Boyce, J.D.; Adler, B. and Bojesen, A.M. (2014): In silico prediction of Gallibacterium anatis pan-immunogens. Vet. Research, 45:80.

Berkhoff, H. and Vinal, A.C. (1986): Congo red medium distinguish between invasive and non invasive Escherichia coli pathogenic for poultry. Avian disease, 30: 117-121.

Bisgaard, M. (1993): Ecology and significance of Pasteurellaceae in animals. Zentralblatt für Bakteriologie, 299, 7-26.

Bisgaard, M.; Korczak, B.M.; BusseKuhnert, H.P.; Bojesen, A.M. and Christensen, H. (2009): Classification of the taxon 2 and taxon 3 complex of Bisgaard within Gallibacterium and description of Gallibacterium melopsittacisp. nov. Gallibacterium trehalosifermentans sp. nov. and Gallibacterium salpinigitis sp. nov. Int. J. Syst. Evol. Microbiol., 59: 735-744.

Bojesen, A.M.; Christensen, J.P. and Bisgaard, M. (2008): Gallibacterium infections and other avian Pasteurellaceae: In Poultry diseases, 6 th 
edition; by (Pattison, M.; McMullin, PF; Bradbury, J.M. and Alexander, D.I.), 160-163.

Bojesen, A.M. and Shivaprasad, H.L. (2007): Genetic diversity of Gallibacterium isolates from California turkeys. Avian Pathol 36: 227-230.

Bojesen, A.M.; Nielsen, S.S. and Bisgaard, M. (2003): Prevalence and transmission of haemoltyic Gallibacterium anatis species in chicken production systems with different biosecurity levels Avian Pathology, 32(5): 503-510.

Bojesen, A.M.; Vazquez, M.E.; Bager, R.J.; Ifrah, D.; Gonzalez, C. and Aarestrup, F.M. (2011): Antimicrobial susceptibility and tetracycline resistance determinant genotyping of Gallibacterium anatis. Veterinary Microbiology, 148:105-110.

Bojesen, A.M.; Vazquez, M.E.; Gonzalez, C.; Robles, F.; Soriano, E.V.; Oslen, J.E. and Christensen, H. (2007): Specific identification of Gallibacterium by PCR using primers targeting the $16 \mathrm{~S}$ rRNA and $23 \mathrm{~S}$ rRNA gene. Vet. Microbiol. 123: 262-269.

Christensen, H.; Bisgarrd, M.; Bosjesen, A.M.; Mutters, R. and Olsen, J.E. (2003): Genetic relationships among avian isolates classified as Pasteurella haemolytica, Actinobacillus salpinigitis or Pasteurella anatis with proposal of Gallibacterium anatis gen. nov., comb. nov. and description of additional genomospecies within Gallibacterium gen. nov. International Journal of systematic and Evolutionary Microbiology, 53: 275-287.

Florence, D.; Andreas, T.; Isabelle, B.; Bozena, M.K.; Yvonne, S.; Peter, K.; Raymond, M. and Joachim, F. (2008): Routine phenotypic identification of bacterial species of the family Pasteurellaceae isolated from animals, J. Vet. Diagn. Invest., 20: 716-724.

Frey, J. and Kuhnert, P. (2002): RTX toxins in Pasteurellaceae, Int. J. Med. Microbiol. 292: 149-158.

Hur, J. and Lee, J.H. (2012): Development of a novel live vaccine delivering enterotoxigenic Escherichia coli fimbrial antigens to prevent post-weaning diarrhea in piglets. Vet. Immunol Immunopathol 146: 283-288.

Jansen R.; Briaire, J.; Smith, H.E.; Dom, P.; Haesebrouck, F. and Kamp, E.M. (1995): Knockout mutants of Actinobacillus pleuropneumoniae serotype 1 that are devoid of Rtx toxins do not activate or kill porcine neutrophils, Infect. Immun. 63: 27-37.

Jones, K.H.; Thornton, J.K.; Zhang, Y. and Mauel, M.J. (2013): A 5-year retrospective report of Gallibacterium anatis and Pasteurella Multocida isolates from chickens in Mississippi Poultry Science Association Inc, 3166-3171.

Kudirkiene, E.; Bager, R.J.; Johnson, T.J. and Bojesen, A.M. (2014): Chaperone-usher fimbriae in a diverse selection of Gallibacterium genomes. BMC Genomics, 15: 1093.

Kristensen, B.M.; Frees, D. and Bojesen, A.M. (2010): GtxA from Gallibacterium anatis, acytolytic RTX-toxin with a novel domain organisation. Vet. Res. 41: 25.

Kristensen, B.M.; Frees, D. and Bojesen, A.M. (2011): Expression and secretion of the RTXtoxin GtxA among members of the genus Gallibacterium. Vet. Microbiol.153: 116-123.

Li, J.X.; Tang, Y.; Gao, J.Y.; Huang, C.H. and Ding, M.J. (2011): Riemerella Anatipestifer Infection in chickens Pak Vet. J., 31(1): 65-69.

Matthew, A.W.; Franklin, R.C.; William, A.C.; Michael, N.D.; George, M.E.; David, W.H.; Janet, F.H.; Donald, E.L.; Daniel, J.S.; Fred, C.T.; John, D.T.; Melvin, P.W.; Barbara, L.Z.; Mary, J.F. and Jana, M.S.CLSI/NCClS (2009): Performance Standards for Antimicrobial Disk Susceptibility Tests, Approval Standard-Tenth Edition and Performance Standards for Antimicrobial Susceptibility Test, M02-A10 and M100-S20.

Mushin, R.; Weisman, Y. and Singer, N. (1980): Pasteurella haemolytica found in the respiratory tract of fowl. Avian Diseases, 24,162-168.

Neubauer, C.; DeSouza-Pilz, M.; Bojesen, A.M.; Bisgaard, M. and Hess, M. (2009): Tissue distribution of haemolytic Gallibacterium anatis isolates in laying birds with reproductive disorders Avian pathology, 38(1): $1-7$.

Olsen, I.; Dewhirst, F.E. and Paster, B.J. (2005): Family Pasteurellaceae. In: Bergeys manual of systemic bacteriology, vol.2, part B,ed. Garrity G.M, pp.851-1083.Springer, New York, NY.

Paudel, S.; Alispahic, M.; Liebhart, D.; Michael Hess, M. and Hess, C. (2013): Assessing pathogenicity of Gallibacterium anatis in a natural infection model: the respiratory and reproductive tracts of chickens are targets for bacterial colonization. Avian Pathology, Vol. 42(6), 527-535.

Sandhu, T.S. and Richard, R.B. (1997): Riemerella anatipestifer infection In: Diseases of poultry Calnek, B.W.(ed) $10^{\text {th }}$ edition, Iowa State University Press, Ames, IA.pp: 161-166.

Scavone, P.; Umpiérrez, A.; Maskell, D.J. and Zunino, P. (2011): Nasal immunization with attenuated Salmonella Typhimurium expressing an MrpA-TetC fusion protein significantly reduces Proteus mirabilis colonization in the mouse urinary tract. J Med Microbiol, 60: 899-904.

Tascon, R.I.; Vazquez-Boland, J.A.; GutierrezMartin, C.B.; Rodriguez-Barbosa, I. and Rodriguez-Ferri, E.F. (1994): The RTX haemolysins ApxI and ApxII are major 
virulence factors of the swine pathogen Actinobacillus pleuropneumoniae: evidence from mutational analysis, Mol. Microbiol. 14: 207-216.

Tatum, F.M.; Briggs, R.E.; Sreevatsan, S.S.; Zehr, E.S.; Ling Hsuan, S. and Whiteley, L.O. (1998): Construction of an isogenic leukotoxin deletion mutant of Pasteurella haemolytica serotype 1: characterization and virulence, Microb. Pathog. 24:37-46.

Vazquez, M.E.; Gonzalez, C. and De laMora, R. and Bojesen, A.M. (2006): Prevalence of Gallibacteriumanatis in Mexico and their effect in laying hens, poster $25-29 / 6-2006.4^{\text {th }}$ International Veterinary and Vaccines Diagnostics Conference, Oslo, Norway.
Wang, C.; Hu, Y.H.; Chi, H. and Sun, L. (2013): The major fimbrial subunit protein of Edwardsiella tarda: vaccine potential, adjuvant effect, and involvement in host infection Fish Shellfish Immunol, 35: 858-865.

Zepeda, V.A.; Calderon-Apodaca, N.L.; Paasch, M.L.; Martin, P.G. and Paredes, D.A. (2010): Histopathologic findings in chickens experimentally infected with Gallibacterium anatis by nasal instillation. Avian Dis. 54: 1306-1309.

Zepeda, A.; Ramirez, S.; Vega, V.; Morales, V.; Talavera, M.; Salgado-Miranda, C.; SimonMartinez, J.; Bojesen, A.M. and SorianoVargas, E. (2009): Hemagglutinating activity of Gallibacterium strains Avian diseases, 53: 115-118.

\title{
عدوى الجاليبكتريوم انيتس في الاجاج والبط
}

\author{
هند كرم عبل السلام ، نبيزة محمود محمد الاطفيحي ، ازهار جابر علي شلبه \\ Email: azhar_gaber@yahoo.com Assiut University web-site: www.aun.edu.eg
}

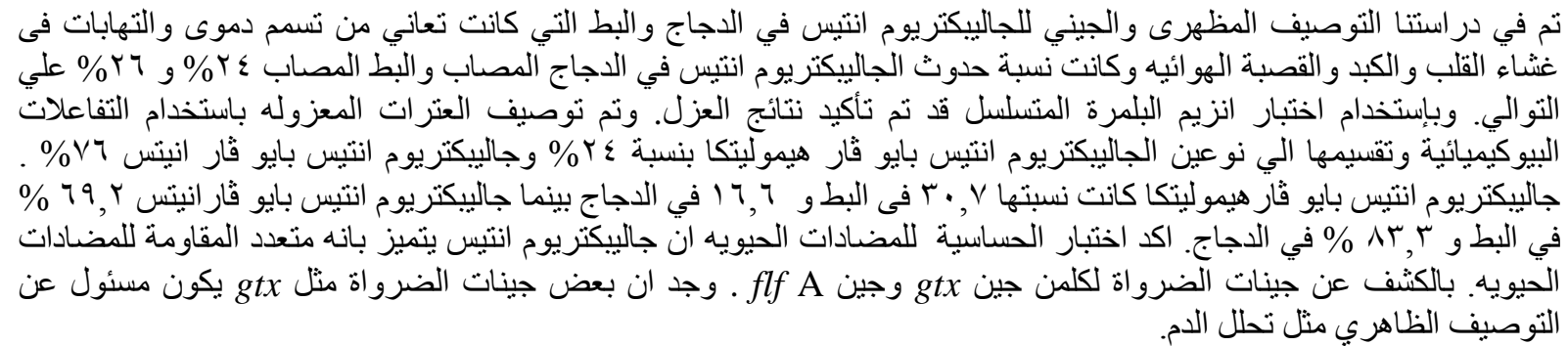

